RACAR : Revue d'art canadienne

Canadian Art Review

RACAR

\title{
Insubordinate, Indiscrete, Interdisciplinary: Cabaret Methods, Adjunct Methods, and Technologies of Fabulous
}

\section{T. L. Cowan}

Volume 43, numéro 1, 2018

URI : https://id.erudit.org/iderudit/1050827ar

DOI : https://doi.org/10.7202/1050827ar

Aller au sommaire du numéro

\section{Éditeur(s)}

UAAC-AAUC (University Art Association of Canada | Association d'art des universités du Canada)

\section{ISSN}

0315-9906 (imprimé)

1918-4778 (numérique)

Découvrir la revue

Citer cet article

Cowan, T. L. (2018). Insubordinate, Indiscrete, Interdisciplinary: Cabaret

Methods, Adjunct Methods, and Technologies of Fabulous. RACAR : Revue d'art canadienne / Canadian Art Review, 43(1), 95-98.

https://doi.org/10.7202/1050827ar

Tous droits réservés (C) UAAC-AAUC (University Art Association of Canada | Association d'art des universités du Canada), 2018
Ce document est protégé par la loi sur le droit d'auteur. L’utilisation des services d'Érudit (y compris la reproduction) est assujettie à sa politique d'utilisation que vous pouvez consulter en ligne.

https://apropos.erudit.org/fr/usagers/politique-dutilisation/ 
intériorisé que je le ressens encore. Je suis consciente de la grande amélioration que représente pour moi l'obtention d'un emploi stable, mais je me sens encore dans une position précaire. Peut-être à cause des constantes menaces de coupures budgétaires à l'université ou du manque de valorisation de notre discipline. Peut-être que ce sentiment d'instabilité s'estompera au cours des ans ou avec mon éventuelle agrégation. Quoi qu'il en soit, je garde, comme mes collègues, des souvenirs mixtes de ces années: I'anxiété de ne pas savoir, d'une semaine à l'autre, d'une année à l'autre, si j'arriverais à joindre les deux bouts, mais aussi la joie de pouvoir travailler dans un domaine dans lequel j'ai été formée et que j'aime, de pouvoir continuer à développer une expertise dans ce domaine, de collaborer à la production et à la publication de connaissances et de rester informée des dernières productions en art et en histoire de l'art.

Ersy Contogouris est professeure adjointe au département d'histoire de l'art et d'études cinématographiques de

l'Université de Montréal et l'ancienne directrice de RACAR.

-ersy.contogouris@umontreal.ca
Insubordinate, Indiscrete, Interdisciplinary: Cabaret Methods, Adjunct Methods, and Technologies of Fabulous

T.L. CoWAN It took me ten years to get my undergraduate degree. The first time around, university was my escape route. I used up all of my bravado getting myself there, as I saw this as the best way to get out of the small town where I was raised, but that was where the plan ended. I paid my way out of that small town with a small portfolio of scholarships, grants, and loans, which I spent in a shockingly short amount of time on tapered jeans and binge drinking. Since I had only ever imagined university as an escape route, and not actually its own thing, I rarely went to class and even more rarely turned in assignments. Very soon I was on academic probation and my student loans were in collection. So I dropped out, got a few jobs in restaurants, started volunteering at some feminist organizations, moved to Vancouver, and became a lesbian spokenword artist. I found my way into the booming feminist and queer spoken-word and broader cabaret scene in Vancouver in the late 1990s. Quite quickly, I realized that in order to meet the feminists and queers I most desired to meet-and to keep a scene going, so I could keep meeting those feminists and queers-I had to make shit happen out of nothing. So, like everyone else I knew, and along with many collaborators, I started making cabaret. This included creating a theme, finding a space, inviting many performers who did different things-with the hope they would invite their friends-making posters, getting the word out, and bringing people together in different configurations depending on the show.

As an event organizer and cabaret curator-although we were certainly not calling ourselves "curators" in those days-I regularly planned shows by inviting people I knew and liked, as well as people I wanted to meet who made work I loved. My collaborators and I made spaces in which we hoped to gather like-minded individuals, which meant 
taking our shows to where feminists and queers were: political rallies, marches, vigils, Take Back the Night, and International Women's Day events. Maybe you know what I'm talking about. We almost never had any money to work with, and even when we charged a cover at the door, we almost never took home any cash. But sometimes we took home a date. We never made solo shows. Each show was a cabaret-a variety show with two, six, or a dozen performers working in poetry, performance art, dance, video, storytelling, puppets, bondage, and so on. All the performers had different life experiences and ways of expressing their ideas. We created stages in whatever show space we could get our hands on: bookstores, cafeterias, sex shops, coffee shops, strip clubs, nightclubs, living rooms, parks, theatres, squatted gallery spaces, bars, community centres, and more than one basement show space so dense with mould spores you choked when you inhaled. Together with the other folks in this scene-and like so many queer, trans, feminist, and other minoritized artists past, present, and future-we created shows in the image of the world in which we wanted to live, bringing into existence a reality that we didn't see elsewhere, designing shows to attract the people we wanted to gather. We hacked together our own existences.

Five years after dropping out of university, with the help of some good people, I went back to school and made it through undergrad, and then eventually through grad school. Several years into my life as a professor, it became very clear that the drop-out years filled with cabaret-making were just as important to the academic life I want for myself as all of the grad courses, exams, and scholarly mentoring. Indeed, it has been the practice of what I have come to call survival interdisciplinarity - a skill I learned while making cabaret-that got me through the most difficult years of my career to date. As a queer, feminist, anti-racist, trans-loving, crip-loving scholar committed to equity in, and the decolonization and Indigenization of corporate settler university culture, cabaret has continued to be my most important skill.

I hope the revolution of adjunct faculty is coming and that it will create a new turn in our disciplines. The "Adjunct Turn," as a set of methods from below, will be aligned with what Chela Sandoval calls "differential oppositional consciousness," ${ }^{\prime}$ coalitional techniques for affinity-based disciplinary and institutional transformations. It is an orientation away from individualism and the life of a solitary, specialized genius, and towards critical intimacy, collaborative, process- and practice-centred distributed epistemologies, and an aesthetics of multiplicity and shared resources. These adjunct methods align with what Audre Lorde called the power of the erotic- "the yes within ourselves," ${ }^{2}$ the yes work of making the intellectual-cultural worlds we desire.

In the midst of completing my undergraduate degree (my third go at it), I started to realize the vast inequalities of the professoriate. It became very clear to me which of my professors worked on contract or in a sessional, parttime, precarious, course-by-course way. Perhaps because I grew up underclass, I can spot another one easily. What this meant was that when I started grad school, I was very determined to never work as a sessional faculty, since I already had a notion of the humiliations that such faculty experienced in the context of my education, and the humiliations of being underclass were not something I wanted to repeat in adulthood.

In the first instance, I got very lucky and did, in fact, go from grad school to a post-doc to a tenure-track job. However, in 2011, I left that tenure-track job in order to move with my partner, who had been offered a job in New York City. Although we didn't have kids, I did what people with children call "keeping our family together," and I took a career risk to live the intimate life I wanted and needed.

My immediate experience in New York City was not the explosive success I had anticipated. No one knew me. My
1. Chela Sandoval, Methodology of the Oppressed (Minneapolis: University of Minnesota Press, 2000), 140.

2. Audre Lorde, Sister Outsider Essays and Speeches (Trumansburg, NY: Crossing Press, 1984), 57. 
reputation did not cross the border. I had to start over. I had signed a part-time contract at The New School, which meant I taught somewhere from one to three courses per year, with a salary cap of something around $\$ 21,000$. If I wanted more work, I had to look elsewhere.

Even though I thought I had previously understood the underclassness of part-time faculty, I soon realized that I had underestimated how my new status as an "adjunct" or "part-timer" would so significantly and negatively impact on the kinds of contributions I would be invited to make at my home institution and beyond. The reality of adjunctism started to set in, and I realized that it was going to be more difficult than I expected to have the life I needed. It was in the context of working from the marginal, isolating, humiliating, and largely unresourced position of an adjunct faculty that cabaret methods became so clearly central to my life as a research-practitioner of trans-feminist and queer cultural and political production. It was in this context that I realized "the state" of our profession and our cross-disciplines in the humanities.

Rather than honing an expertise in a small, specialized area of research, it became clear to me that I needed to be able to mobilize my capacity for indiscretion-I had to be able and willing to teach absolutely anything, anywhere. The cross-disciplinary, make-do training of my ongoing cabaret worlds bolstered this practice. In academic industries, the precariat work where we can, when we can, and how we can This is adjunct methodology.

And it is in these conditions that we find the "state" of our disciplines and our profession. What is the work being done by adjunct faculty in the classrooms, conferences, and research cultures of the professoriate? What are the conditions of the desperate, degrading, crushing, strategic-survival economies of part-time and contract professorial labour? How can our profession and disciplines account for and value these knowledges, even when our

institutions treat that labour as infinitely replaceable, disposable, unspecialized, and undisciplined? These are questions I continue to ask myself, even as I find myself with the advantage of a new tenure-track position. Importantly, I owe this new position to the solidarity, patience, generous help, understanding, and recognition of feminist comrades along the way. We cannot survive in this system without making worlds that we want to be in together; tenured and tenure-track faculty have to acknowledge that it is their/our job to simultaneously work and break this corrupt, vastly unjust system. We have to pay attention to how our departments, faculties, and institutions use contract faculty in ways that become increasingly invisible to those of us protected from such realities in the daily life of our jobs.

And when we sit on hiring committees and grant juries, we need to be attentive to the inclination of our profession to punish the undisciplined for their insubordinate expertise in everything - an insubordination produced by the need to create something awesome from nothing, while living out the conditions of massive and unforgivable collegial neglect. The survival work of adjunct faculty needs to be acknowledged as a specialization-as an expertise-in our disciplines and in the research and teaching economies of the contemporary university.

I would like to end with a story-a dispatch from the stage of the Loud \& Queer Festival in Edmonton many years ago. It is a story that has shaped my intellectual and creative life, and it offered me a survival practice that I used constantly when I worked as an adjunct faculty. The story comes from the Edmonton Queen, Gloria Hole, and her drag mother, Halifax-based drag queen high priestess Lulu LaRude. ${ }^{3}$ When Gloria was just a baby queen (so, in the early 1980s), she and Lulu were offered a gig out in Gibbons, north of Edmonton. They were booked for a show at a place called Sensations or Celebrities or Hot Spot, or something very gay sounding. For weeks before, an excited Gloria had told all of her friends that she'd booked a
3. I would like to thank Darrin Hagen (aka Gloria Hole) for permission to re-tell this story. 
FEATURE gig; she just couldn't stop talking about it. It turns out the place was a strip club with patrons who were not impressed by these drag queens, and Gloria and Lulu barely escaped with their lives.

They got back in their dragmobile and high-tailed it back to (the relative safety of) Edmonton. As they drove, poor young Gloria turned to the wise Lulu and said, "Oh Lulu what are we going to tell everyone? I'm so ashamed." Wise Lulu turned to Gloria and said, "Darling, have I taught you nothing? We're going to tell them it was FabULOUS."

The risk of being fabulous, as many a drag queen knows, is the risk of being under-appreciated and misunderstood, disciplined by a life-threatening set of rules by which you're not even playing. I propose that we all begin to appreciate and reward the fabulous as it is mobilized by faculty working in the shittiest of conditions. As Anjali Arondekar and Geeta Patel note in their introduction to the recent special issue of GLQ, "Area Impossible: The Geopolitics of Queer Studies":

[W]e have opted for the fabular because it can be thought of as the form through which one imagines a better or perhaps just a good enough analytic. Fables underscore peculiar commonalities and repetitions of belief and orient routinized habits of analysis while attending to the generation of value/capital that is implicit in both. [Whereas] translation (especially in embodied elsewheres) could inadvertently slide into literalization, punctiliousness, or conversion, mislaying in the process the fecundity that the fabular can lug along. ${ }^{4}$

I suggest that we need to recognize and reward the fabulous in our fields, not only to work to eradicate the entrenched and enforced maldistribution of resources and life chances within our profession, disciplines, and institutions, but also to begin to assess and appreciate the radical disciplinary transformations at work through the $\mathrm{X}$ - factor $^{5}$ specialties of colleagues working across realities as adjunct faculty. The fabular is the practice of creating and holding what is necessarily generative for ourselves and those who listen to our stories in the face of obvious disaster; 6 it is a "good-enough" analytic for these times and I propose that this is the analytic from which we are all working, adjunct or otherwise; to operate securely is to disavow the situation that produces these massive inequities in our places of education. As Tavia Nyong'o writes of fabulation, "The overriding of our rational brain is key to how fabulation, as an instinct for the virtual, unlocks and unleashes novelty in an otherwise deadlocked symbolic order." ${ }^{7}$ suggest that we first identify and seize upon that symbolic order in which we are deadlocked, and then we must begin the cabaret work of fabulating a new set of realities.

T.L. Cowan is Assistant Professor in the Department of Arts,

Culture, and Media at the University of Toronto.

-tl.cowan@utoronto.ca

4. Anjali Aronkedar and Geeta Patel,

A version of this essay was previously published at hook \& eye. ${ }^{8}$ It was based on a talk I originally gave at the 2017 Universities Art Association of Canada (UAAC) at the BanffCentre, which is located on the traditional territory of the Kootenay, Stoney, Blood, Peigan, Siksika, and Tsuu T'ina First Nations.

I would like to thank to Andrea Terry and Riva Symko for inviting me to be part of the panel A Big Dull Axe Looms Large: Interrogating the Disciplinary Relevance of Art $\&$ Art History in Canada, during which I dedicated my paper to the Ontario Public Service Employees Union (OPSEU/SEFPO) faculty, who were striking at the time(October 2017), and who put their bodies and livelihoods on the line to improve working conditions for part-time and full-time faculty in Ontario's colleges. Thanks also to the many comrades I have talked with throughout the years about adjunct methods, precarious faculty survivance, and feminist solidarity across the institutiona and community differences of rank and resources, includingeveryonewhotaugh and comm me how to do cabaret, but especially the Feminist Technology Network (FemTech-
Net), for teaching me about true collegial solidarity across differences of academic rankand situation. Thanks also to hook \& eye co-editor Erin Wunker, with whom I've been having these conversations for manyyears. duction," GLQ: A Journal of Lesbian and Gay Studies, 22, 2 (2016): 154.

5. Beth Coleman, Hello Avatar: Rise of the Networked Generation (Cambridge, MA The MIT Press, 2011), 3

6. T.L. Cowan and Jasmine Rault, Transmedial Drag: Cabaret Methods, Digital Platforms \& Technologies of Fabulous," lecture delivered at Trinity College, Department of American Studies, February $25,2016$.

7. Tavia Nyong'o, “Wildness: A Fabulation," S\&FOnline 12, 1-2, http://sfonline. barnard.edu/activism-and-the-academy/ wildness-a-fabulation/ (accessed October 6, 2017).

8. T.L. Cowan, "Guest Post: Insubordinate, Indiscrete, Interdisciplinary: Risking Perpetual Precarity in All the Wrong Places, or Just Being Fabulous, Manifesto, "hook Geje, November 2017, https://hookandeye.ca/2017/11/20/ 2017, https://hookandeye.ca/2017/11/2
guest-post-insubordinate-indiscreteinterdisciplinary-risking-perpetual-precarity-in-all-the-wrong-places-or-justbeing-fabulous-a-manifesto/(accessed February 20, 2018). 